\title{
LINKAGE MAP OF THE LONG ARM OF BARLEY CHROMOSOME 3 USING C-BANDS AND MARKER GENES
}

\author{
I. LINDE-LAURSEN \\ Agricultural Research Department, Risø National Laboratory \\ DK-4000 Roskilde, Denmark
}

Received 25.i.82

\begin{abstract}
SUMMARY
The long arm of barley chromosome 3 can be divided into four segments by three $\mathrm{C}$-band locations. From the centromere the segments comprise 4 per cent, 26 per cent, 34 per cent, and 36 per cent of the arm length. The segregation of $114 \mathrm{~F}_{2}$-plants showed a 1:2:1-ratio for $\mathrm{C}$-bands at the three locations. No recombination was observed between the two proximal C-band locations whereas the two distal locations recombined with a frequency of $12 \pm 2$ per cent. The three C-band locations were linked with loci cer-zd, $u z$, and cer-zn, but not with the tightly linked loci Est-1 and Est-4. The order of and distance (in per cent rec.) among the three cytological markers and the three marker gene loci were: $3 l 1-<1$ per cent $-3 l 2-2 \pm 1$ per cent $-c e r-z d-2 \pm 1$ per cent $-u z-8 \pm 2$ per cent $-3 l 3-16 \pm 3$ per cent - cer- $z n$. A comparison of cytological distances and linkage values suggests that recombination is virtually confined to the distal half of this chromosome arm. In addition, C-bands at one location on chromosomes 6 and 7, respectively, segregated in 1:2:1-ratios. The C-band location on chromosome 6 and the Amy-1 locus were linked with a recombination percentage of $23 \pm 3$ per cent. The usefulness of multiple marker stocks is discussed.
\end{abstract}

\section{INTRODUCTION}

BARLEY has a low level of chiasma formation in proximal parts of most chromosome arms (Gale and Rees, 1971; Rick, 1971). Thus, as in other organisms, inconsistencies probably exist between the "genetic" positions of gene loci as indicated on linkage maps and their actual physical or "cytological" positions on the chromosomes. Until recently, it was difficult to compare "genetic" and "cytological" positions in barley, since the only accurately localized cytological markers were the primary and secondary constrictions and a few translocation breakpoints (Hagberg et al., 1975, 1978). However, chromosome banding techniques have revealed a number of bands allowing the identification of the chromosomes by their banding patterns and showing sufficient band heteromorphism to warrant their utilization in cytogenetic studies (for references see Linde-Laursen, 1981). The present investigation was undertaken (a) to compare the "cytological" and the "genetic" positions of three C-band locations on the long arm of chromosome 3, and (b) to locate the three band locations relative to five marker gene loci on the linkage map of the same chromosome arm.

\section{MATERIALS AND METHODS}

The $114 \mathrm{~F}_{2}$-plants of cultivated barley, Hordeum vulgare $\mathrm{L}_{\text {., }}$ were derived from 115 seeds sown from reciprocal crosses between the Danish 
variety 'Tystofte Prentice' and a multiple marker stock. The $10 \mathrm{~F}_{1}$ plants involved were grown in a growth room with alternating periods of light $\left(30,000\right.$ lux, $18 \mathrm{~h}$, about $\left.21^{\circ} \mathrm{C}\right)$ and darkness $\left(6 \mathrm{~h}\right.$, about $\left.14^{\circ} \mathrm{C}\right)$. The two parental lines were differentiated by $\mathrm{C}$-bands at five locations and by genes at six loci (table 1 ; figs. 1 and 2). The bands were designated as previously described (Linde-Laursen, 1979). The three loci cer(eceriferum)- $z d, u z$ (semibrachytic or uzu), and cer-zn are linked in this order with cer-zd in the centromere area on the long arm of chromosome 3. Genes $u z$ and $c e r-z n^{244}$ were indicated as linked with C-band $3 / 3+$ (cf. fig. 1) as the markers had been retained together in the marker gene stock through six backcrosses. The tightly linked loci, Est-1 (esterase isoenzyme) and Est-4, both with co-dominant alleles, are distally located on the long arm of chromosome 3 (Nielsen and Hvid, 1976). The Amy-1 ( $\alpha$-amylase isoenzyme) locus, also with co-dominant alleles, is located on the long arm of chromosome 6.

TABLE 1

C-bands and marker genes differentiating the barley variety 'Tystofte Prentice' and the multiple marker stock

\begin{tabular}{ccccl} 
& $\begin{array}{c}\text { Chromosomal } \\
\text { location }\end{array}$ & T. Prentice & $\begin{array}{c}\text { Multiple marker } \\
\text { stock }\end{array}$ & \multicolumn{1}{c}{ References } \\
C-bands & 3 & $3 l 1-$ & $3 l 1+$ & Linde-Laursen, 1979 \\
& 3 & $3 l 2+$ & $3 l 2-$ & Linde-Laursen, 1979 \\
& 3 & $3 l 3-$ & $3 l 3+$ & cf. fig. 1 \\
& 6 & $6 s 1-$ & $6 s 1+$ & Linde-Laursen, 1979 \\
Genes & 7 & $7 s 3-$ & $7 s 3+$ & Linde-Laursen, 1979 \\
& 3 & $C e r-z d$ & $c e r-z d^{67}$ & Søgaard, 1977 \\
& 3 & $U z$ & $u z$ & Søgaard, 1977 \\
& 3 & $C e r-z n$ & $c e r-z n^{244}$ & Søgaard, 1977 \\
& 3 & $E s t 1 P r$ & $E s t 1 C a$ & Hvid and Nielsen, 1977 \\
& 3 & $E s t 4 S u$ & $E s t 4 A t$ & Hvid and Nielsen, 1977 \\
& 6 & $A m y 1 B i$ & $A m y 1 K e$ & Nielsen and Frydenberg, \\
& 3 & & & 1974
\end{tabular}

The C-banding and isoenzyme techniques described by Linde-Laursen (1975, 1978), Frydenberg et al. (1969), and Hvid and Nielsen (1977), respectively, were used. Linkage was estimated in two-point tests by the method of maximum likelihood. A $\chi^{2}$-value was calculated to test the two-point segregations at the recombination frequency estimated. Threepoint tests are strongly advocated by many and were also calculated, but they gave no more information than the two-point ones (cf. Jensen, 1981). The C-banded karyotype of each $\mathrm{F}_{2}$-plant was based on the banding patterns in at least four metaphases from two root tips.

The genotypes with respect to the morphological markers of each $F_{2}$-plant were determined on the phenotypes of at least $30 \mathrm{~F}_{3}$-plants (per $F_{2}$-plant) grown in the field in 1980 and 1981 . However, due to poor seed set and/or poor germination the offspring of seven $F_{2}$-plants comprised between 8 and 16 plants only. The scoring for the cer-zd locus proved difficult in the given gene background. It was moreover influenced by the unsuspected segregation of chlorina plants in some $\mathrm{F}_{2}$-offspring. $\alpha$-amylase and esterase isoenzymes were scored on $\mathrm{F}_{2}$-plants. 


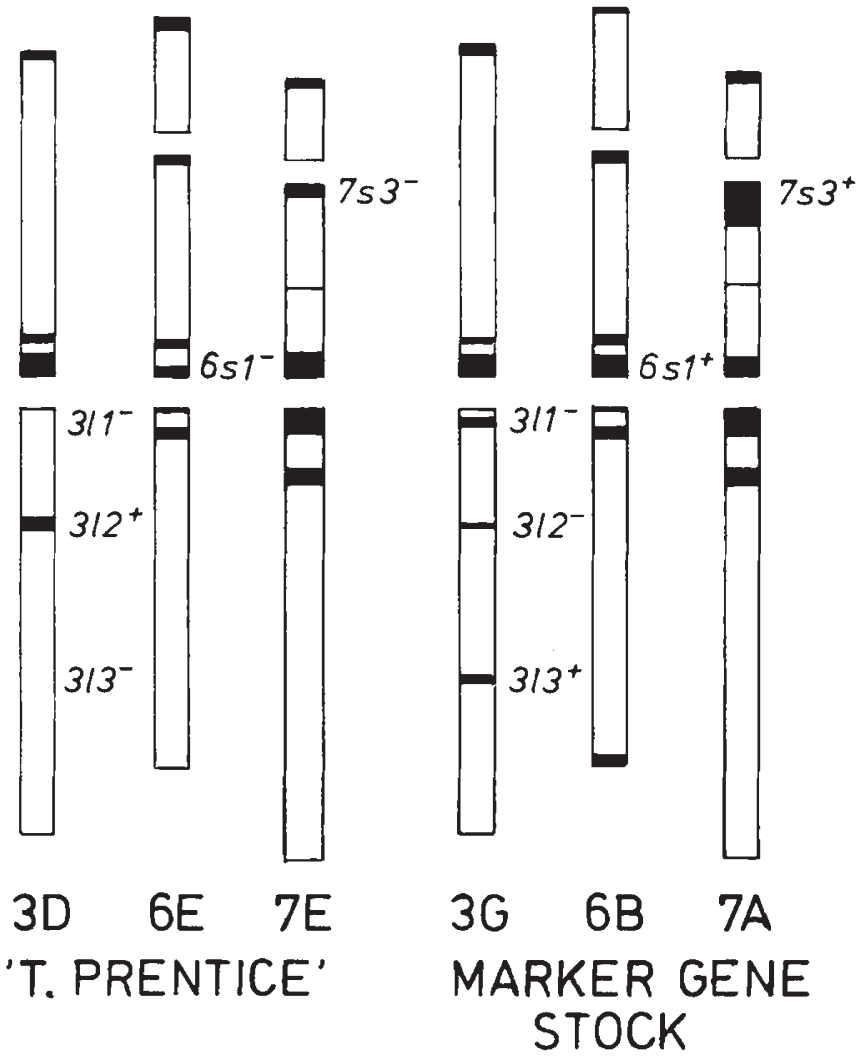

FIG. 1.-Giemsa C-banding pattern variants of chromosomes 3,6, and 7 of 'Tystofte Prentice' and marker gene stock (for designations of C-bands and banding patterns, see text and Linde-Laursen, 1981).

The four distances from the centromere as calculated from the proximal boundary of C-band $3 l 1+$, the midpoints of C-bands $3 l 1+, 3 l 2+$ and $3 l 3+$, and the arm end were measured to the nearest $0.5 \mathrm{~mm}$ with a ruler from sketches of 23 specimens of chromosome 3 of the variety 'Montcalm' drawn after projections of photographic negatives (ultimate magnification $\times 14,250$ ). The distance to the centromere is approximate since it does not include the small non-C-banding segment at the centromere (cf. fig. 1).

\section{RESUlts}

\section{(i) Linkage relationships}

The results of the reciprocal crosses were combined because no statistically significant difference was detected. The particulars of the segregations of the C-bands and the genes at loci $c e r-z d, u z$, and cer-zn on chromosome 3 are given in table 2 . The $\mathrm{C}$-bands at the five $\mathrm{C}$-band locations and the alleles at the six marker gene loci segregated according to the expected $1: 2: 1$ ratio (table 3 ). 


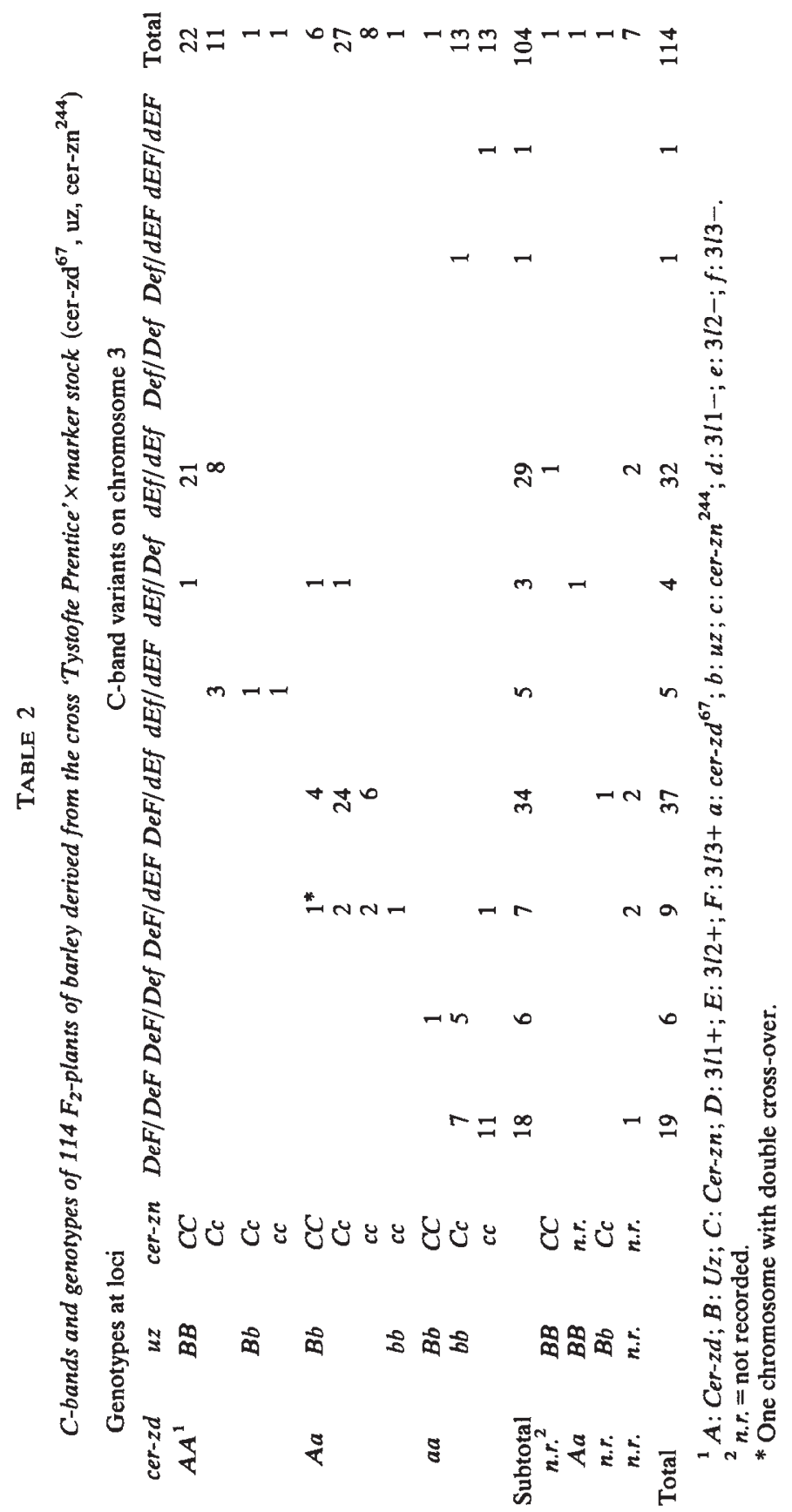




\section{Plate I}

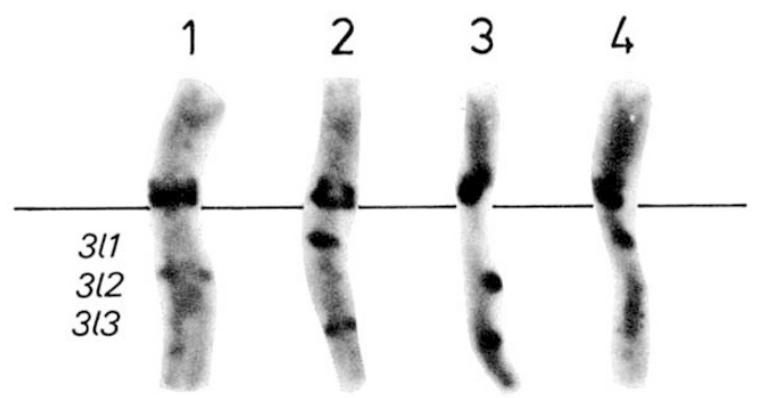

FIG. 2.-Variation in Giemsa C-banding patterns at locations $3 / 1,3 / 2$, and $3 / 3$ in the long arm of barley chromosome 3 of 'Tystofte Prentice' (1), marker gene stock (2), and two $F_{2} C$-band recombinants $(3,4)$, respectively. 
TABLE 3

Segregations of single $C$-bands and marker genes on chromosomes 3, 6, and 7 among $F_{2}$-plants

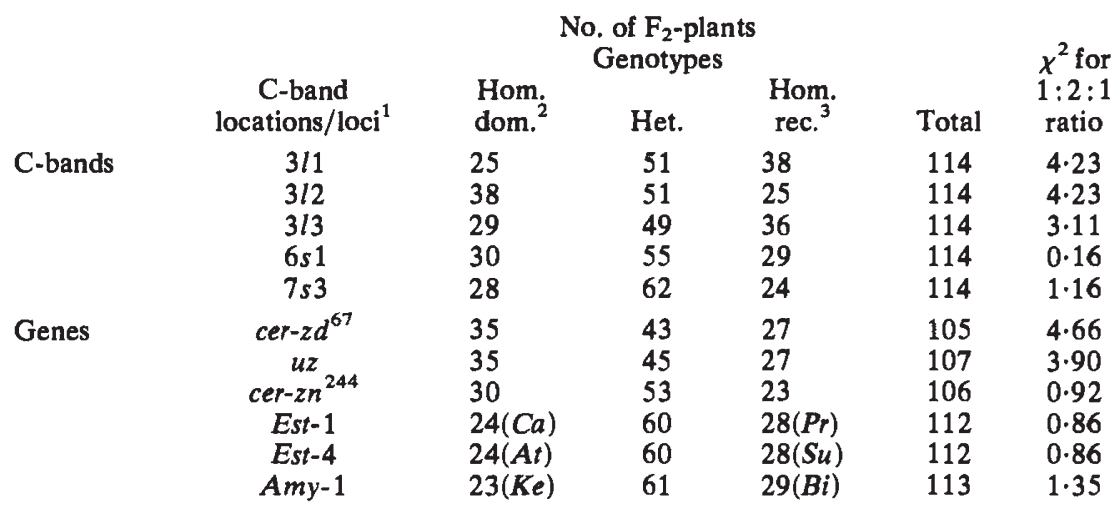

1 cf. fig. 1 and table 1.

${ }^{2} \mathrm{C}$-bands designated + .

${ }^{3} \mathrm{C}$-bands designated -.

\section{(a) C-bands on chromosome 3}

The "cytological" distances separating the centromere, the three C-band locations, and the end of the long arm of chromosome 3 were $0.3 \pm 0.02 \mu \mathrm{m}$, $1.8 \pm 0.09 \mu \mathrm{m}, 2.4 \pm 0.11 \mu \mathrm{m}$, and $2.5 \pm 0.06 \mu \mathrm{m}$, respectively. This corresponds with 4 per cent, 26 per cent, 34 per cent, and 36 per cent of the arm length (fig. 3).

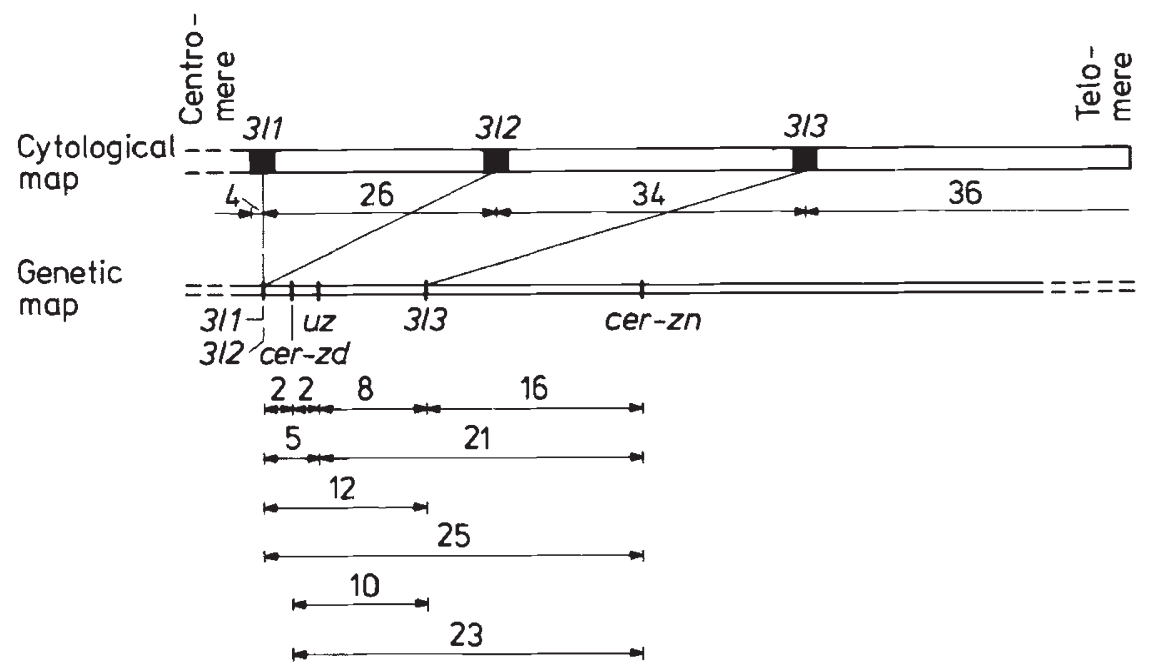

FIG. 3.-Cytological and genetic maps of the long arm of barley chromosome 3. Distances on the cytological map in per cent of arm length. Distances on the genetic map in per cent recombination. 
No recombinant involving C-bands at the two proximal locations on chromosome 3 was found (table 4, cross 1) although their "cytological" distance equals about one-fourth the length of the chromosome arm. This agrees with the results of a former experiment (Linde-Laursen, 1979). By adding the results of the experiment to those of the present one, the upper limit of the recombination frequency between the two C-band locations was estimated to be less than 1 per cent at the 95 per cent significance level.

TABLE 4

Recombination frequencies for $C$-bands and marker genes on barley chromosomes 3 and 6 based on $F_{2}$-genotypes from the cross 'Tystofte Prentice' $(311-, 312+, 313-$, Cer-zd, Uz, Cer-zn, Est $1 \mathrm{Pr}$, Est4Su, Amy1Bi) $\times$ marker stock $\left(311+, 312-, 313+\right.$, cer-zd ${ }^{67}$, uz, cer-zn ${ }^{244}$, Est1Ca, Est4At, Amy1Ke)

\begin{tabular}{|c|c|c|c|c|c|}
\hline \multirow{2}{*}{$\begin{array}{l}\text { Cross } \\
\text { no. }\end{array}$} & $\begin{array}{l}\text { C-band(s) or genotype(s) of } \\
\text { cross combinations }\end{array}$ & \multirow[b]{2}{*}{ Rec. \% } & \multirow[b]{2}{*}{ \pm S.D. } & \multirow[b]{2}{*}{$\chi^{2 *}$} & \multirow[b]{2}{*}{ d.f. } \\
\hline & (T. Prentice) $\quad \times \quad$ (Marker stock) & & & & \\
\hline \multicolumn{5}{|c|}{ Chromosome 3} & \\
\hline $\begin{array}{r}1 \\
2 \\
3 \\
4 \\
5 \\
6 \\
7 \\
8 \\
9 \\
10 \\
11 \\
12 \\
13 \\
14\end{array}$ & 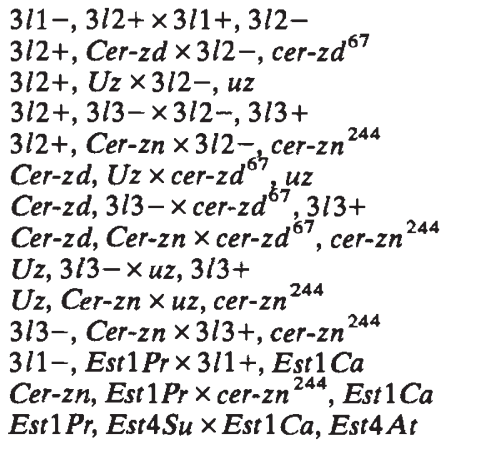 & $\begin{array}{r}0 \\
2 \cdot 4 \\
4 \cdot 8 \\
12 \cdot 3 \\
24 \cdot 9 \\
2 \cdot 4 \\
10 \cdot 4 \\
23 \cdot 4 \\
7 \cdot 7 \\
20 \cdot 6 \\
16 \cdot 3 \\
47 \cdot 2 \\
54 \cdot 1 \\
0\end{array}$ & $\begin{array}{l}1 \cdot 07 \\
1 \cdot 49 \\
2 \cdot 17 \\
3 \cdot 54 \\
1 \cdot 07 \\
2 \cdot 24 \\
3 \cdot 45 \\
1 \cdot 91 \\
3 \cdot 19 \\
2 \cdot 81 \\
4 \cdot 70 \\
4 \cdot 81\end{array}$ & $\begin{array}{r}71 \cdot 10 \\
19.79 \\
9.59 \\
6.96 \\
4.87 \\
8.07 \\
8.20 \\
8.20 \\
9.43 \\
4.66 \\
6.79 \\
5.88\end{array}$ & $\begin{array}{l}7 \\
7 \\
8 \\
7 \\
7 \\
7 \\
7 \\
7 \\
7 \\
7 \\
7 \\
7\end{array}$ \\
\hline \multicolumn{5}{|c|}{ Chromosome 6} & \\
\hline 15 & $6 s 1-, A m y 1 B i \times 6 s 1+, A m y 1 K e$ & $22 \cdot 6$ & $3 \cdot 26$ & $6 \cdot 69$ & 7 \\
\hline
\end{tabular}

* Deviation from the ratios expected at the rec. per cent estimated.

The recombination frequency between the C-bands at $3 / 2$ and $3 / 3$ (fig. 1) was only $12 \cdot 3 \pm 2 \cdot 17$ per cent (table 4 , cross 4 ) although their "cytological" distance is about one-third the length of the chromosome arm (fig. 3 ). In this two-point test $\mathrm{C}$-banding made it possible to separate the double heterozygous type $(A a B b)$ into two, viz. that derived from non-crossover gametes $(A B / a b)$ and that derived from crossover gametes $(A b / a B)$.

\section{(b) Marker gene loci on chromosome 3}

The recombination frequency between loci cer-zd and $u z$ (table 4, cross 6) was significantly smaller than that $(12.5 \mathrm{~cm} \sim 12.2$ per cent) reported by Søgaard (1977) whereas the recombination frequencies between loci $u z$ and cer-zn (table 4, cross 10) and between loci cer-zd and cer-zn (cross 8) agreed with her values $(17 \cdot 2 \mathrm{~cm} \sim 16.6$ per cent and $29.7 \mathrm{~cm} \sim 26.6$ per 
cent). The size of the three recombination frequencies is in accordance with the order cer- $z d, u z, c e r-z n$ of the three loci.

No recombinant involving genes at loci Est-1 and Est-4 was observed (table 4, cross 14) testifying to their close linkage (cf. Hvid and Nielsen, 1977). Based on the present material the recombination frequency was estimated to be less than 2.6 per cent at the 95 per cent significance level. In agreement with their distal location (Nielsen and Hvid, 1976), the two esterase loci had high recombination frequencies with all C-band locations and all other loci on chromosome 3 (table 4, crosses 12 and 13).

\section{(c) C-bands and marker gene loci on chromosome 3}

"Cytological" distances among C-bands and recombination frequencies among C-bands, marker gene loci, and C-bands and marker gene loci, respectively, show (table 4 , fig. 3) (a) that C-bands and loci cer-zd, $u z$, and cer- $z n$ are linked, but that none of these markers is linked with loci Est-1 and Est-4, (b) that the most likely order of the markers is $3 l 1,3 l 2$, $c e r-z d, u z, 3 l 3, c e r-z n$, but that the size of the standard deviations indicates that the order of C-band location $3 / 3$ and the marker gene loci remains uncertain, and (c) that the genetic distances among the markers is: $3 l 1-$ $3 / 2<1$ per cent, $3 l 2-c e r-z d 2.4 \pm 1 \cdot 07$ per cent (table 4 , cross 2 ), cer- $z d-$ $u z 2 \cdot 4 \pm 1 \cdot 07$ per cent (cross 6$), u z-3 l 37 \cdot 7 \pm 1.91$ per cent (cross 9 ), and $3 / 3-$ cer-zn $16 \cdot 3 \pm 2 \cdot 81$ per cent (cross 11 ).

Only one $F_{2}$-plant had a type (indicated by an asterisk in table 2) suggesting that on one chromosome 3 there had been a double-crossover, viz. one crossover between $u z$ and C-band location $3 / 3$ and one between $3 l 3$ and locus cer-zn. The coefficient of coincidence was 0.38 agreeing with previous results based on recombinations among the three loci: cer-zd, $u z$, and cer-zn (Søgaard 1977).

Although the number of expected plants in many cases was too low to calculate a correctly distributed $\chi^{2}$-value, $\chi^{2}$-values were calculated to test the two-gene ratios expected at the recombination frequencies estimated (table 4). In two of the two-point tests with low recombination frequencies (crosses 2 and 3) high $\chi^{2}$-values were obtained, suggesting some deviation from the expected segregation.

\section{(d) C-bands and locus Amy-1 on chromosome 6}

The centromeric C-bands at location $6 s 1$ in the short arm of chromosome 6 (fig. 1) and the Amy-1 locus recombined with a frequency of $22 \cdot 6 \pm 3 \cdot 26$ per cent (table 4 , cross 15 ). This agrees with a previous finding of $26 \cdot 2 \pm 5 \cdot 45$ per cent recombination between markers (Linde-Laursen, 1979).

\section{Discussion}

The results of the experiment clearly show that in barley C-bands may be used as genetic markers thereby rendering it possible to locate C-bands on the genetic chromosome map and to place genes on the "cytological" map. Further, they illustrate that recombination may take place at different frequencies in different segments of the barley chromosomes (cf. fig. 3). 
The part of the long arm of chromosome 3 covered by the three C-band locations comprises nearly two-thirds of the "cytological" arm length, but only a genetic length of about $12 \mathrm{~cm}$. As the "cytological" length of the whole arm equals those of the long arms of chromosomes 5 and 7 it may be assumed that all three arms have similar genetic lengths, viz. about $100 \mathrm{~cm}$ (Jensen, 1980, 1981). In combination, these things suggest (a) that as in many other organisms, crossing-over and recombination are virtually confined to the distal half of this chromosome arm, and (b) that the centromeric area on the linkage map corresponds to a major part of the proximal chromosome segment on the "cytological" map. In accordance with this, linkage studies using translocations place locus cer-zd in "the centromere area" and locus ert-c, closely linked with, but distal to, cer-zd (Søgaard, 1977), "near the centromere" (Persson, 1969a, b).

The large difference between the recombination frequencies between loci cer-zd and $u z$ as observed in this study and by Søgaard (1977) can hardly be reconciled. A possible cause of the difference might be a structural difference between the chromosomes of the plants of the marker gene stocks used.

The one- and two-point tests comprising the linked markers on chromosome 3 indicated a clear deficit of heterozygotes, a clear surplus of homozygotes having a genotype similar to that of the parent 'Tystofte Prentice' (cf. tables 1 and 3), and in some combinations a small deficit of the other parental type. The skewed segregation for these genes contrasts with that for the other markers (table 3). This suggests the existence of a factor on the chromosome 3 segment carrying the genes $c e r-z d^{67}, u z$, and $c e r-z n^{244}$ which affects this; it might be the cause also of the chlorina phenotype observed among some $F_{2}$-offspring, and of the sterility observed in some $F_{2}$-plants.

The skewed $\mathrm{F}_{2}$-segregations show that multiple marker stocks may not always be as useful in genetic studies as expected. Firstly, markers, especially induced ones, often have smaller or larger deleterious effects on plant vigour that may be enhanced when the markers are combined. Secondly, the chromosome segment between linked markers may continue to carry unobserved additional characters even through a number of backcrosses because the segment is selected as a whole. After combination such characters may become exposed.

In spite of foreseen difficulties in classifying the $F_{2}$-plants by their C-banding patterns (Linde-Laursen, 1979) the variation in size and position of the C-band variants used was sufficient for a safe identification, indicating the value of some $\mathrm{C}$-bands as cytogenetic markers. However, the limited variation in size of $\mathrm{C}$-bands at most hitherto identified locations, combined with the mostly proximal positions of the latter that place them in areas in which recombination normally seems to be absent, restricts their usefulness for barley cytogenetics. More C-band variation is present in the wild barley, Hordeum vulgare L. ssp. spontaneum (C. Koch) Thell. (LindeLaursen, 1981) but the exploitation of this variation will demand its incorporation into the genome of cultivated barley.

Acknowledgments. - Bodil Søgaard is thanked for seeds of the triple marker gene stock and helpful discussions, J. Jensen for help with the statistics, and Mrs Elly Ibsen and Mrs Hanne Johansen for rendering skilful technical assistance. 


\section{REFERENCES}

FR YDENBERG, O., NIELSEN, G., AND SANDFAER, J. 1969. The inheritance and distribution of $\alpha$-amylase types and DDT responses in barley. Z. Pflanzenzüchtg., 61, 201-215.

GALE, M. D., AND REES, H. 1971. The production and assay of segmental substitution lines in barley. Genet. Res., 17, 245-256.

HAGberG, A., LeHMANN, L., AND hagberG, P. 1978. Segmental interchanges in barley. II. Translocations involving chromosomes 6 and 7. Z. Pflanzenzüchtg., 81, 89-110.

HAGBERG, G, LEHMANN, L., AND hAGBERG, P. 1975. Segmental interchanges in barley. I. Translocations involving chromosomes 5 and 6. Hereditas, 80, 73-82.

HVID, S., AND NIELSEN, G. 1977. Esterase isoenzyme variants in barley. Hereditas, 87, 155-162.

JENSEN, J. 1980. Coordinator's report: Chromosome 5. Barley Genet. Newslett., 10, 88-90.

JENSEN, J. 1981. Construction of a barley chromosome 7 linkage map. Proc. 4th Int. Barley Gen. Symp. (Edinburgh), (in press).

LINDE-LAURSEN, I. 1975. Giemsa C-banding of the chromosomes of 'Emir' barley. Hereditas, 81, 285-289.

LINDE-LAURSEN, I. 1978. Giemsa C-banding of barley chromosomes. I. Banding pattern polymorphism. Hereditas, 88, 55-64.

LINDE-LAURSEN, I. 1979. Giemsa C-banding of barley chromosomes. III. Segregation and linkage of C-bands on chromosomes 3, 6, and 7. Hereditas, 91, 73-77.

LINDE-LAURSEN, I. 1981. Giemsa banding patterns of the chromosomes of cultivated and wild barleys. Proc. 4th Int. Barley Gen. Symp. (Edinburgh), (in press).

NIELSEN, G., AND FR YDENBERG, O. 1974. Linkage between the loci Amy-1 ( $\alpha$-amylase), o (orange lemma) and $x_{n}$ (xantha seedling). Barley Genet. Newslett., 4, 53-54.

NIELSEN, G., AND HVID, s. 1976. Location of the esterase locus Est-1 on barley chromosome 3. Barley Genet. Newslett., 6, 45-46.

PERSSON, G. 1969 a. An attempt to find suitable genetic markers for dense ear loci in barley. I. Hereditas, 62, 25-96.

PERSSON, G. $1969 b$. An attempt to find suitable genetic markers for dense ear loci in barley. II. Hereditas, 63, 1-28.

RICK, C. M. 1971. Some cytogenetic features of the genome in diploid plant species. Stadler Symposia, 1-2, 153-174.

SØGAARD, B. 1977. The localization of eceriferum loci in barley. V. Three point tests of genes on chromosome 1 and 3 in barley. Carlsberg Res. Comm., 42, 67-75. 